\title{
UNCOVERING STUDENTS' ATTITUDE TOWARD VLOGGING ACTIVITIES IN IMPROVING STUDENTS' SPEAKING ABILITY
}

\author{
by \\ Berlinda Mandasari ${ }^{1}$ \\ Universitas Teknokrat Indonesia \\ berlinda@teknokrat.ac.id \\ Dyah Aminatun ${ }^{2}$ \\ Universitas Teknokrat Indonesia \\ Aminatun.dyah@gmail.com
}

Received; August 28, 2019

Resent; September 21, 2019

Accepted: October 18, 2019
Reviewed: September 19, 2019

Revised: October 1, 2019

Published: October 19, 2019

\begin{abstract}
:
The objective of this study is to uncover the students' attitude toward vlogging activities in improving students' speaking ability. Participants of this study are 40 students majoring English Education who enrolled in transactional conversation subject at Universitas Teknokrat Indonesia. Research design used in this study is descriptive qualitative. Data were gained through questionnaire exposing students' attitude toward the subject and students' attitude toward using vlog to support learning process. There were 11 indicators with 32 questionnaire items. The results of this study reveal that Vlog helps students to understand the materials, improve students' learning achievement, motivation, creativity, and engagement, provide interesting learning activities, efficient learning, effective learning, and lead students to be confident, independent and critical.
\end{abstract}

Keywords: Vlog, Attitude, English learning, transactional conversation

\section{INTRODUCTION}

Rapid development of technology has affected all aspects of life, including education. Education 4.0 as a response to industrial revolution 4.0 puts much attention on using technology as a tool to support teaching and learning. Digital literacy becomes the key point enabling people get in touch to this era. Learning language will be much easier as long as we connect the process using technology. In English language teaching, speaking skill becomes one of important skills to teach. The objective of learning speaking skill is that students are able to communicate in English fluently. The fact is that some students thought that speaking skill is one of the most avoided skills in English (Guo, 2013). Students are afraid of making mistakes, being bullied, and unconfidence (Tajizan et al, 2012). Moreover, practicing speaking in the classroom takes time. Students have less participation in speaking class.

Premise Journal Vol. 8 No 2, October 2019, e-ISSN: 2442-482x, p-ISSN: 2089-3345, p.214-225 
As a solution, blended learning model can be applied. Blended learning model provides a combination of a face-to-face learning and online learning (McCarthy, M.A, \& Murphy, E.A, 2010). A face-to-face learning usually takes place in the classroom, while an online learning can be done anytime and anywhere utilized by technology.

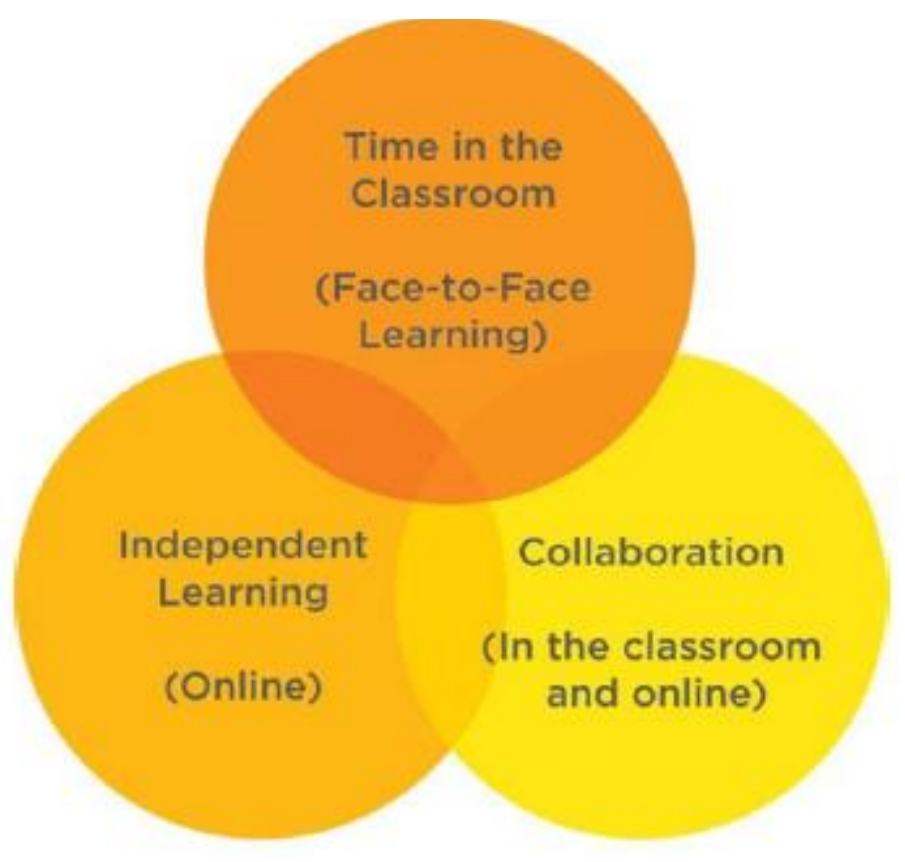

Picture 1. Concept of Blended Learning model

One of model that can be applied is Video blog (Vlog). Vlog is an activities in which people create a video about themselves sharing about daily activities, personal life, their interest, tourism destination, culinary, and many aspects that possibly attract people to watch the video through online. One of the media that can be used to share people's video is YouTube. Some studies conducted to find out the effectiveness of Vlog in language learning. Hakim, Muhammad Iqbal Ali Akbar (2016, 44-48) revealed that vlog can improve students' English proficiency. Other research also revealed that Vlogs are very effective to increase students' satisfaction in learning English as Second language (Shis, Ru-Chu, 2010:883-897). Aydin (2014, 244-259) revealed that vlog has positive impact in developing interaction between students and lecturers using target language. In accordance with its development, vlogs are designed to provide experience for users in expressing personal experience then shared in website network.

Based on the explanation above, the researcher is interested in finding students' attitude toward using Vlog in transactional conversation subject. These vlogging activities have been implementing during the class. 


\section{METHOD}

The design of this research is qualitative study in which the data were analyzed by using descriptive analysis. Participants of this research were 40 students of English Education study program at Universitas Teknokrat Indonesia. These students enrolled in Transactional Conversation subject. The objective of this subject is to improve student's ability to communicate about hotel and tourism well by delivering speech/presentation and making conversation. Supporting students to achieve the learning objective, there was a policy in which all students were obliged to participate in fieldtrip program. This program was done on March until April 2019. The trip destinations were Bali, Yogyakarta, and Jakarta. During this trip, students were assigned to create their vlog reviewing some tourism destination and traditional culinary. These assignment were done in a group consist of three to four students. It is expected that students could discuss with their friends about their vlog and prepare for an interesting vlog.

To gain data, the researcher administered questionnaire. These questionnaires are used to gain students' information about their attitude in learning English by using Vlog. The questionnaire is constructed from theory of attitude. The questionnaire will be in the form of Likert Scale. There are four scales ranging from Strongly Agree (SA), Agree (A), Disagree (DS) and Strongly Disagree (SDS) started from 4-1 respectively. The result of this research can be used as a recommendation whether vlog is effective to be applied. The evaluation criteria to measure students attitude is in the form of percentage of students' answer on the questionnaire.

\section{FINDINGS AND DISCUSSION}

The result of the questionnaire reveals that most students have positive attitude toward vlog. Most students agree that vlog improves students' understanding toward English materials, increase students' language achievement in transactional conversation subject, provide interesting activities in language learning, lead students to be an autonomous learner, improve students' motivation, creativity, self engagement, confident and critical thinking. The detail explanation can be seen below. 


\section{A. Improving students' understanding toward English materials}

Table 1. Students' understanding toward English materials

\begin{tabular}{llllll}
\hline No & Questionnaire Items & SA & A & DS & SDS \\
\hline $\mathbf{1}$ & $\begin{array}{l}\text { Vlog helps me to understand the material in } \\
\text { Transactional Conversation class }\end{array}$ & $15 \%$ & $82,5 \%$ & $2,5 \%$ & 0 \\
$\mathbf{2} \quad \begin{array}{l}\text { Vlog improves my understanding toward the } \\
\text { materials being discuss }\end{array}$ & $15 \%$ & $82,5 \%$ & $2,5 \%$ & 0 \\
$\mathbf{4} \quad \begin{array}{l}\text { I found some interesting references to learn } \\
\text { English }\end{array}$ & $\mathbf{2 7 , 5 \%}$ & $70 \%$ & $2,5 \%$ & 0 \\
$\mathbf{1 5} \quad$ I can easily finish my task & $\mathbf{1 5 \%}$ & $\mathbf{6 7 , 5 \%}$ & $17,5 \%$ & 0 \\
Average & & $\mathbf{7 5 , 6 5 \%}$ & $\mathbf{6 , 2 5 \%}$ & $\mathbf{0 \%}$ \\
\hline
\end{tabular}

The table above shows us the result of questionnaire. It can be seen that $18,13 \%$ of total students strongly agree with the statements. Moreover, 75,65\% students do agree that vlog helps students to understand English materials, provide interesting references to learn English, and help students to finish their tasks easily. Yet, 6,25\% of them disagree with the statement. According to Rakhmanina and Kusumaningrum (2017), it can be notified that Videoblogging is recommended in speaking classes. This strategy helps the student to improve their communication skill, disciplinary, social interaction, learning awareness, and motivation.

\section{B. Improving Students' Language Achievement in Transactional Conversation Subject}

Another component of students' attitude toward vlog is that vlog increases students' achievement in transactional conversation subject. The result of questionnaire can be seen as follows:

Table 2. Students' Students' Language Achievement in Transactional Conversation Subject

\begin{tabular}{llllll}
\hline No & Questionnaire Items & SA & A & DS & SDS \\
\hline $\mathbf{3}$ & I got many new English vocabularies & $25 \%$ & $72,5 \%$ & $2,5 \%$ & 0 \\
$\mathbf{5}$ & $\begin{array}{l}\text { I got knowledge about culture where I do my } \\
\text { vlogging activities }\end{array}$ & $32,5 \%$ & $62,5 \%$ & $5 \%$ & 0 \\
$\mathbf{6}$ & $\begin{array}{l}\text { Vlog increases my score in this subject } \\
\mathbf{9}\end{array}$ & $\begin{array}{l}\text { I can easily explain the tourism destination and } \\
\text { traditional culinary because I was there to }\end{array}$ & $82,5 \%$ & $7,5 \%$ & 0 \\
& & & $72,5 \%$ & $2,5 \%$ & 0 \\
\hline
\end{tabular}

Premise Journal Vol. 8 No 2, October 2019, e-ISSN: 2442-482x, p-ISSN: 2089-3345, p.214-225 


\begin{tabular}{llllll}
\hline $\mathbf{1 0}$ & I can speak English fluently & $5 \%$ & $72,5 \%$ & $20 \%$ & 0 \\
$\mathbf{1 1}$ & I can speak English with correct grammar & $7,5 \%$ & $72,5 \%$ & $20 \%$ & 0 \\
& Average & $\mathbf{1 7 , 5 \%}$ & $\mathbf{7 2 , 5 \%}$ & $\mathbf{9 , 5 \%}$ & $\mathbf{0 \%}$ \\
\hline
\end{tabular}

The data above shows us the result of questionnaire determining students' attitude toward vlog. It can be seen that $72,5 \%$ students agree that vlog increases students' achievement in transactional conversation subject. Students get many new vocabularies, knowledge about culture, increased score. Furthermore, students can easily explain the tourism destination and traditional culinary, speak English fluently with good grammar. Moreover, another $17,5 \%$ of students strongly agree about that statement. Only 9,5\% of total students disagrees. This result is also supported by a research conducted by Maulidah (2017). She found that vlog significantly improve students' speaking ability. According to Lestari, N (2019), video blog can enrich students with a variety of knowledge about vocabulary, grammar, pronunciation, accent, and knowledge of culture.

\section{Providing Interesting Activities in Language Learning}

Table 3. Interesting Activities in Language Learning

\begin{tabular}{llllll}
\hline No & Questionnaire Items & SA & A & DS & SDS \\
\hline $\mathbf{1 2}$ & I am happy learning English through Vlog & $17,5 \%$ & $67,5 \%$ & $15 \%$ & 0 \\
$\mathbf{2 1}$ & I am happy with learning process that I & $10 \%$ & $82,5 \%$ & $7,5 \%$ & 0 \\
& have done & & & \\
$\mathbf{2 9}$ & Vlog creates an interesting learning process & $10 \%$ & $80 \%$ & $10 \%$ & 0 \\
& Average & $\mathbf{1 2 , 5 \%}$ & $\mathbf{7 6 , 7 \%}$ & $\mathbf{1 0 , 8 \%}$ & $\mathbf{0 \%}$ \\
\hline
\end{tabular}

The data above shows us the students' attitude toward vlog in terms of its effectiveness in providing interesting activities. $12,5 \%$ of total students strongly agree that they feel happy during vlogging activities. They also can create an interesting content on their YouTube channel. Moreover, 76,7\% students agree with the statements. Only 10,8\% of total students disagree with the statements. According to Rahayu, A.S., \& V. Nurviyani (2018), vlog makes students interested in learning speaking because vlog is new instructional media for teacher and students, learning speaking though vlog is fun and not boring as usual, students' are motivated to improve their speaking skill. 


\section{Leading students to be autonomous learners}

Table 4. Students as Autonomous learner

\begin{tabular}{llllll}
\hline No & Questionnaire Items & SA & A & DS & SDS \\
\hline $\mathbf{1 3}$ & Vlog helps me to be an autonomous learner & $15 \%$ & $75 \%$ & $10 \%$ & 0 \\
$\mathbf{2 0}$ & I am challenged to learn English by using Vlog & $5 \%$ & $80 \%$ & $15 \%$ & 0 \\
& Average & $\mathbf{1 0 \%}$ & $\mathbf{7 7 , 5 \%}$ & $\mathbf{1 2 , 5 \%}$ & $\mathbf{0 \%}$ \\
\hline
\end{tabular}

Vlog leads students to be autonomous learners. $10 \%$ and $77,5 \%$ of total students strongly agree and agree with the statements. They respond that vlog help them learn English independently. They are even challenged to learn it. However, 12,5\% students disagree with the statements. The result of this study is in accordance to Maulidah (2017). She found that Vlog gives an exposure on autonomousity toward the students. They are free to manage their ideas related to their learning process. Vlog provides students with autonomous learning.

\section{E. Improving students' motivation}

Table 5. Students' Motivaton

\begin{tabular}{llllll}
\hline No & Questionnaire Items & SA & A & DS & SDS \\
\hline $\mathbf{1 4}$ & I am motivated to learn English by using Vlog & $12,5 \%$ & $80 \%$ & $7,5 \%$ & $0 \%$ \\
\hline
\end{tabular}

Data above show us that vlog has something to do with students' motivation. $12,5 \%$ and $80 \%$ of total students strongly agree and agree with the statements. Yet, 7,5\% students disagree with the statement. According to Flynn (1998), video helps the students to understand the instruction more then use a textbook because: "video bring language in the context of life in realistic settings to the classroom". It means video can help learners to face the real world.

Besides, the video can be an effective way to get students ${ }^{e e}$ attraction and increase their motivation. The other side, with video the teaching-learning process is more flexible accessible and memorable and video can bring the new information. According to Sari (2017), incorporating vlog in YouTube Channel in teaching helped to improve students' motivation and confidence of Intermediate 1 level of LB-LIA Jambi. Bringing technology into teaching and learning process is now proven to be one of the most effective way to improve students' general performance in quite significant result. 


\section{F. Providing efficient learning}

Table 6. Positive Statement of Efficient Learning

\begin{tabular}{llllll}
\hline No & Questionnaire Items & SA & A & DS & SDS \\
\hline $\mathbf{3 0}$ & Vlog is efficient to be applied & $30 \%$ & $62,5 \%$ & $5 \%$ & $2,5 \%$ \\
\hline
\end{tabular}

Vlog is effective to be applied. It can be seen from the result of questionnaire in which $30 \%$ students strongly agree and $62,5 \%$ agree with the statement. However, $5 \%$ disagree and $2,5 \%$ strongly disagree.

Table 7. Negative Statement of Efficient Learning

\begin{tabular}{|c|c|c|c|c|c|}
\hline No & Questionnaire Items & $\mathbf{S A}$ & $\mathbf{A}$ & DS & SDS \\
\hline 16 & $\begin{array}{l}\text { I must have mobile data when I want to find } \\
\text { some rerefences and create my own vlog }\end{array}$ & $15 \%$ & $52,5 \%$ & $20 \%$ & $2,5 \%$ \\
\hline 17 & $\begin{array}{l}\text { It takes more time to learn English using Vlog } \\
\text { because I need to prepare all the things that I } \\
\text { want to tell }\end{array}$ & $2,5 \%$ & $47,5 \%$ & $45 \%$ & $5 \%$ \\
\hline 27 & $\begin{array}{l}\text { I don't have good quality of camera. It hampers } \\
\text { me a lot }\end{array}$ & $2,5 \%$ & $30 \%$ & $42,5 \%$ & $25 \%$ \\
\hline \multirow[t]{2}{*}{28} & I feel depressed talking in front of camera & $5 \%$ & $15 \%$ & $72,5 \%$ & $7,5 \%$ \\
\hline & Average & $\mathbf{7 , 5 \%}$ & $36 \%$ & $46,5 \%$ & $8 \%$ \\
\hline
\end{tabular}

The result of questionnaire reveals that students must have mobile data to find some references to create their own vlog. It can be seen from the data in which $15 \%$ students strongly agree and 52,5\% agree with the statement. Besides, students found that it takes more time to learn English. It means that learning English using vlog provides more time for students. $47,5 \%$ students agree with this issue. Yet, $45 \%$ students disagree with the issue.

Vlogging activities require students to have a good camera to result good quality video. Students' response whether they have good quality of camera varies. 2,5\% strongly agree that they don't have good quality camera. 30\% agree with the issue. However, $42,5 \%$ students disagree, and another $25 \%$ strongly disagree. It means that $67,5 \%$ students have good quality camera on their own. It can be seen from the result of videos. 
The last statement is whether students feel depressed talking in front of camera. 5\% students strongly agree, $15 \%$ students agree. However, 72,5\% and another 7,5\% disagree and strongly disagree. It indicates that $80 \%$ students do not feel depressed talking in front of camera.

\section{G. Providing effective learning}

Table 8. Effective Learning

\begin{tabular}{llllll}
\hline No & Questionnaire Items & SA & A & DS & SDS \\
\hline $\mathbf{1 8}$ & $\begin{array}{l}\text { Learning English through vlog can be done } \\
\text { anytime and anywhere }\end{array}$ & $15 \%$ & $77,5 \%$ & $7,5 \%$ & 0 \\
& Vlog is effective to be applied & $7,5 \%$ & $82,5 \%$ & $10 \%$ & 0 \\
& Average & $\mathbf{1 1 , 2 5 \%}$ & $\mathbf{8 0 \%}$ & $\mathbf{8 , 7 5 \%}$ & $\mathbf{0}$ \\
\hline
\end{tabular}

Vlog provides an effective learning. Learning English through Vlog can be done anytime and anywhere. $80 \%$ and 11,25\% students agree and strongly agree with the statements. Yet, 8,75\% students disagree. According to Lestari, N (2019), video blog as the learning media to help students' in improving speaking skill is effective because its usage has many advantages compared to its disadvantages, as for the existing challenges, it could be anticipated and solved by each student.

\section{H. Improving Students' Creativity}

Tabel 9. Students' Creativity

\begin{tabular}{llllll}
\hline No & Questionnaire Items & SA & A & DS & SDS \\
\hline $\mathbf{1 9}$ & Vlog helps me to be creative in finishing the & $15 \%$ & $72,5 \%$ & $12,5 \%$ & 0 \\
& tasks given by my lecturer & & & & \\
\multirow{2}{*}{$\mathbf{2 3}$} & Vlog gives me more time to talk & $10 \%$ & $82,5 \%$ & $7,5 \%$ & 0 \\
& Average & $\mathbf{1 2 , 5 \%}$ & $\mathbf{7 7 , 5 \%}$ & $\mathbf{1 0 \%}$ & $\mathbf{0}$ \\
\hline
\end{tabular}

Vlog helps to improve students' creativity. They were given more time to talk during vlogging. $77,5 \%$ and $12,5 \%$ students agree and strongly agree. Only $10 \%$ students do not agree. Vlogging, as stated by Lee (2017), is a kind of activity done by a single 
person talking to a camera around of topics, including personal topics or those relating to the wider world. This medium of speaking helped learners to communicate more in improving their fluency, vocabulary, grammatical aspects and to reduce anxiety (Anil, 2016). They can also be more creative by speaking their own experience or story.

\section{Vlog improves students' engagement toward learning process}

Table 10. students' engagement toward learning process

\begin{tabular}{llllll}
\hline No. & Questionnaire Items & SA & A & DS & SDS \\
\hline $\mathbf{2 2}$ & Vlog helps me to participate in learning process & $10 \%$ & $75 \%$ & $15 \%$ & 0 \\
$\mathbf{3 2}$ & Vlog gives me chance to work in a group & $10 \%$ & $85 \%$ & $5 \%$ & 0 \\
& Average & $\mathbf{1 0 \%}$ & $\mathbf{8 0 \%}$ & $\mathbf{1 0 \%}$ & $\mathbf{0}$ \\
\hline
\end{tabular}

Vlog helps students to participate in learning process. It also gives chances for students to work in a group. $80 \%$ and $10 \%$ students agree and strongly agree with the statements. $10 \%$ disagree. According to Caze (2017), Using blogs and vlogs in the classroom enhanced students' engagement and their desire to produce writing of a high quality. For some students, the blogging platform linked to their own experience of creating texts and sharing media; for other students, it provided them with the knowledge, understanding and skills to inspire them to be publishers of meaningful text in the future.

In addition, Harmer (2001) states that, "video could be supplied simulations, not only because it could give feedback when students could be watched themselves and evaluate their performances, but also because the presence of the video helped to make students feel more realistic". In short, it can be concluded that real activities support students' engagement in learning process.

\section{J. Vlog leads students to be confident}

Table 11. Students' Confidence

\begin{tabular}{llllll}
\hline No & Questionnaire Items & SA & A & DS & \multicolumn{1}{c}{ SDS } \\
\hline $\mathbf{2 4}$ & Vlog leads me to be confident speaking in & $\mathbf{1 2 , 5 \%}$ & $\mathbf{7 2 , 5 \%}$ & $\mathbf{1 7 , 5 \%}$ & $\mathbf{2 , 5 \%}$ \\
& English & & & & \\
\hline
\end{tabular}


Vlog helps students to be confident in speaking English. It can be seen from the result of questionnaire. $12,5 \%$ strongly agree with the statement. $72,5 \%$ students agree, and the rest disagree and strongly disagree. This finding is in line with a study conducted by Rahayu, A.S. \& Nurviyani, V (2018). They found that the students more confident and courage in speaking after taking a look at the result of videos.

\section{K. Vlog leads students to have critical thinking}

Table 12. Students' Critical thinking

\begin{tabular}{llrlll}
\hline No & Questionnaire Items & SA & A & \multicolumn{1}{l}{ DS } & SDS \\
\hline $\mathbf{2 5}$ & Vlog leads me to have critical thinking & $\mathbf{1 0 \%}$ & $\mathbf{7 2 , 5 \%}$ & $\mathbf{1 7 , 5 \%}$ & $\mathbf{0}$ \\
\hline
\end{tabular}

Vlog helps students to be critical. It can be seen from the questionnaire that $10 \%$ students strongly agree, $72,5 \%$ students agree and another $17,5 \%$ students disagree. According to Ebrecht (2015), it is highlighted that blogging promotes meaningful communication and develops critical and analytical thinking, along with collaborative and reflective skills. O’Byrne and Murrell (2014) stated that blogging helps students to construct meaning and participate in meaningful dialogue within and beyond the classroom

\section{CONCLUSION}

Based on the finding and discussion above, it can be concluded that students have positive attitude toward video blog in improving students' speaking ability. It helps students understand the English materials, improve language learning achievement, motivation, creativity, students' engagement, provide interesting activities, efficient learning, effective learning, lead autonomous learning, confident, and critical thinking. For further discussion, the implementation of vlog as a web-based medium provides a wide chance to debate. It can come from the idea of the process of implementing and the evaluation to minimize error from students.

\section{BIO-Profile}

Berlinda Mandasari is a lecturer at the English Education Study Program of Universitas Teknokrat Indonesia. She obtained her Master's degree from Universitas Sebelas Maret. 
Her research interests are, Teaching Media, Teaching Assessment, Teaching Strategy, Teaching English as Foreign Language, and English for Business.

\section{REFERENCES}

Anil, B. (2016). Top-Up Students Second Language Talk Time through Vlogs. Indonesian Journal of EFL and Linguistics, 1(2), 129-143.

Aydin, S. (2014). The use of blogs in learning English as a foreign language. Mevlana International Journal of Education (MIJE), 4(1). 244-259.

Caze, Sarah Le. Changing classroom practice through blogs and vlogs. Literacy Learning:the Middle Years, 25(1), 16-27.

Ebrecht, B.M. (2015). A case study of classroom blogging in three elementary schools. Journal of Educational Research and Innovation, 4(1), 1-22

Guo, R. X. (2013). The Use of Video Recordings as an Effective Tool to Improve Presentation Skills. Polyglossia, 24, 92-101.

Hakim, Muhammad Iqbal Ali Akbar. (2016). The use of video in teaching English Speaking. Journal of English and Education, 4(2), 44-48.

Harmer, J. (2001). The Practice of English Language Teaching. Edinburg: Pearson Education Ltd. J. S. F. S. C. A. Gretchen Lowerison, "Student perceived effectiveness of computer technology use in post-secondary classrooms," Computer \& Education, 47(1), 25.

Kartikasari, N. (2018). The Implementation of Project Based Learning by Making Vlog in Teaching Speaking of Recount Text for Junior High School. RETAIN. 6 (3), 124133.

Lee, Sarah. (2017). Style-Shifting in Vlogging. An Acoustic Analysis of "Youtube Voice”. Lifespan \& Styles: Undergraduate Working Paper on Instrapsaker Variation, 3(1).doi: 10.2218/ls.v3i1.2017.1826

Lestari, N. (2019). Improving the Speaking Skill by Vlog (Video Blog) as Learning Media:The EFL Students' Perspective. International Journal of Academic Research in Business and Social Sciences. 9 (1), 915-925.

Maulidah, Izzah. (2017). Vlog: the Mean to Improve Students' Speaking Ability. Proceeding of International Conference on English Language Teaching. Accessed on August 1, 2019.

Maulidah, I. (2017, August). Vlog: the Mean to Improve Students' Speaking Ability. In International Conference on English Language Teaching (ICONELT 2017). Atlantis Press. 
McCarthy, M.A, \& Murphy, E.A. (2010). Blended Learning: Beyond initial use to helping to solve real-world academic problems: Journal of College Education \& Learning, 7(6), 67-70.

O'Byrne, B., \& Murrell, S. (2014). Evaluating multimodal literacies in student blogs. British Journal of Educational Technology, 45(5), 926-940.

Rahayu, A.S.,\& Nurviyani, V. (2018). A Study of Students' Spekaing Skill through Vlog. Journal of English Pedagogy, Liguistics, Literature, and Teaching. 6(2). $1-9$.

Nurviyani, V., \& Rahayu, A. S. (2018). A STUDY OF STUDENTS'SPEAKING SKILL THROUGH VLOG. Jurnal JOEPALLT (Journal of English Pedagogy, Linguistics, Literature, and Teaching), 6(2).

Rakhmanina, L \& Kusumaningrum, D (2017). The Effectiveness of Video Blogging in Teaching Speaking Viewed from Students' Learning Motivation. Proceeding of The $5^{\text {th }}$ International Seminar on English Language and Teaching. Accessed on August 19, 2018.

Sari, Pramitha. (2017). Using Vlog in the Youtube Channel as a Means To Improve Students' Motivation And Confidence to Speak English in Intermediate 1 Level of LB-LIA Jambi. International Journal of English Language and Teaching. 1(1), 36-44.

Shis, Ru-Chu. (2010). Blended Learning using video-based blogs: public speaking for English as a second language students. Australasian Journal of Educational Technology, 26(6), 883-897.

Sihem, Suci. (2012). Using Video techniques to Develop Students' Speaking Skill. Algeria: Biskra University.

Sun, Yu-Chih. (2009). Voice Blog: An Exploratory Study of Language Learning. Language Learning \& Technology.13(2), 88-103.

Tajizan, F. N., Ab Rahim, S., Abdul Halim, F. S., Abdullah, A., Ismail, I. N., Cochrane, T. A. (2012). Implementing a Virtual Presentation Program in ESL Classrooms. International Journal of e-Education, e-Business, e-Management and e-Learning, 2(3), 1-5. 